\title{
CHARACTERIZATION OF AUJESZKY'S DISEASE VIRUS ISOLATES FROM SOUTH AND SOUTHEAST BRAZIL BY RFLP ANALYSIS
}

\author{
Rosa Maria Piatti ${ }^{1 *}$; Alice Akimi Ikuno ${ }^{1}$; Elenice Sequetin Cunha' ${ }^{1}$, Régia D’Ambros²; \\ Fábio Gregori ${ }^{3}$; Rodrigo Martins Soares ${ }^{4}$; Adriana Cortez ${ }^{3}$; Leonardo José Richtzenhain ${ }^{3}$ \\ ${ }^{1}$ Laboratório de Imunologia, Instituto Biológico, São Paulo, SP, Brasil. ${ }^{2}$ Cedisa, Concórdia, Santa Catarina, SC, Brasil. \\ ${ }^{3}$ Faculdade de Medicina Veterinária e Zootecnia, Universidade de São Paulo, SP, Brasil. \\ ${ }^{4}$ Instituto de Ciências Biomédicas, Universidade de São Paulo, SP, Brasil.
}

Submitted: August 28, 2000; Returned to authors for corrections: January 15, 2001; Approved: June 21, 2001

\begin{abstract}
The genomic DNA of thirty strains of Aujeszky's disease virus (ADV) isolated in the South and Southeast regions of Brazil from 1982 to 1996 were characterized by restriction endonuclease analysis with BamHI. Twenty seven strains were isolated from pigs, 1 from cattle, 1 from cat and 1 from dog. Using a systematization previously described, the $30 \mathrm{ADV}$ strains could be classified as genomic types I $(\mathrm{n}=2)$ and II $(\mathrm{n}=28)$. Genomic type III was not observed. In this first study of genomic type characterization of brazilian ADV strains, we could demonstrate the occurence in Brazil of the genomic types I and II, with a large predominance of genomic type II.
\end{abstract}

Key words: Aujeszky's disease virus, swine, genomic RFLP, Brazil

\section{INTRODUCTION}

Aujeszky's Disease is spread worldwide and has been considered an important cause of economic losses in pig husbandry (19). Pigs are the only known reservoir of Aujeszky's Disease Virus (ADV), which is classified as a Suid herpesvirus-1, Herpesviridae Family, Alphaherpesvirinae Sub-Family and Varicellovirus Genus (11).

$\mathrm{ADV}$ is perpetuated in pig herds by alternating latency with reactivation in the host. ADV may cause mass mortality among piglets, growth losses in fattening pigs and reproductive disorders in adults. Domestic and wildlife animals may occasionally acquire the infection through contact with pigs, presenting an inevitably fatal outcome (19).

Grouping field strains of ADV into distinct serotypes has not been possible. Therefore, other markers such as cytopathogenic effect in cell cultures, pathogenicity to mice and rabbits, inactivation by UV radiation, trypsin treatment and heat sensitivity have been studied as attempts for ADV characterization $(2,3,13)$. Genomic types of ADV strains based on Restriction Fragment Length
Polymorphism (RFLP) patterns with the endonuclease BamHI were associated to viral geographic and chronological distribution in many countries $(6,8)$.

Pig population of Brazil reaches $3.5 \times 10^{6}$ animals and the South and Southeast regions are considered the most important producing areas. Although many ADV strains have been isolated in those regions $(10,14)$, genomic typing of Brazilian ADV strains has never been accomplished.

The aim of the present study was to characterize the genomic types of 30 ADV strains isolated in South and Southeast Brazil, from 1982 to 1996.

\section{MATERIALS AND METHODS}

\section{ADV strains}

Thirty ADV strains isolated from 1982 to 1996 in the States of São Paulo, Paraná and Santa Catarina were studied. All strains were isolated from cerebral tissue: 27 from pigs, 1 from cattle, 1 from dog and 1 from cat. The Bartha ADV strain was used as reference and was kindly supplied by Solvay Laboratories -

\footnotetext{
* Corresponding author. Mailing address: Laboratório de Imunologia, Instituto Biológico, Caixa Postal 12898. 04014-002, São Paulo, SP, Brasil. Fax: (+5511) 5087-1755, E-mail: piatti@biologico.br
} 
Campinas - São Paulo-Brazil. ADV strains were grown at $37^{\circ} \mathrm{C}$ on PK-15 cells in $1,500 \mathrm{~cm}^{2}$ roller bottles. After total cytopathic effect, virus suspensions were frozen at $-80^{\circ} \mathrm{C}$.

\section{Genomic DNA extraction}

Viral suspensions were thawed and cellular debris removed by centrifugation at $16,000 \mathrm{x} g$ for 10 minutes at $4^{\circ} \mathrm{C}$. Supernatant was layered onto a $3 \mathrm{~mL}$ cushion of $40 \%(\mathrm{w} / \mathrm{v})$ sucrose in PBS $(0.01 \mathrm{M}$ $\left.\mathrm{PO}_{4}-/ 0.15 \mathrm{M} \mathrm{NaCl}\right) \mathrm{pH} 7.2$ and centrifuged at $100,000 \mathrm{x} g$ for 1 hour at $4^{\circ} \mathrm{C}$. Viral pellet was resuspended in $1 \mathrm{~mL}$ of TNE (Tris $0.01 \mathrm{M}$, EDTA 0.001M, $\mathrm{NaCl} 0.1 \mathrm{M}) \mathrm{pH} 8.0,0.5 \%$ SDS and $0.2 \mathrm{mg}$ proteinase $\mathrm{K} / \mathrm{mL}$ and incubated for 1 hour at $56^{\circ} \mathrm{C}$. DNA was extracted by phenol-chloroform treatment as described by Sambrook et al. (15).

\section{RFLP analysis and genomic typing}

Viral genomic DNA $(5 \mu \mathrm{L})$ was digested to completion with $5 \mathrm{U}$ of BamHI according to manufacturer's instructions (PharmaciaSweden). Digested DNA was subjected to electrophoresis at $30 \mathrm{~V}$ for 18 hours at $4^{\circ} \mathrm{C}$ on a $0.7 \%$ agarose gel in Tris-Borate-EDTA ( 45 $\mathrm{mM}$ Tris, $45 \mathrm{mM}$ borate and $1 \mathrm{mM}$ EDTA) $\mathrm{pH}$ 7.5.

After electrophoresis, the gel was stained with ethidium bromide $(5 \mu \mathrm{g} / \mathrm{mL})$ and photographed on a UV transiluminator. Genome typing of ADV strains by RFLP was performed according to Herrmann et al. (8) and Christensen (6).

Following this systematization (Fig. 1), the migration pattern of the first three fragments can be used for genomic typing of ADV strains. The genomic type II has an extra cleavage site in the fragment 2 which leds to the appearance of two new fragments $2 \mathrm{a}$ and $2 \mathrm{~b}$, located bellow the fragment 3 (not shown). The genomic type III lacks a restriction site between the fragments 2 and 9, with the appearance of a fragment $(2+9)$ just bellow the fragment 1 .

\section{RESULTS AND DISCUSSION}

Using the BamHI/ RFLP analysis (Fig. 2, lane B), the Bartha reference ADV strain confirmed its classification as genomic type I (8).

Among the 30 ADV strains isolated in South and Southeast Brazil over a 14 year period, 2 strains could be classified as genomic type I and 28 strains as genomic type II. Typical BamHI/RFLP

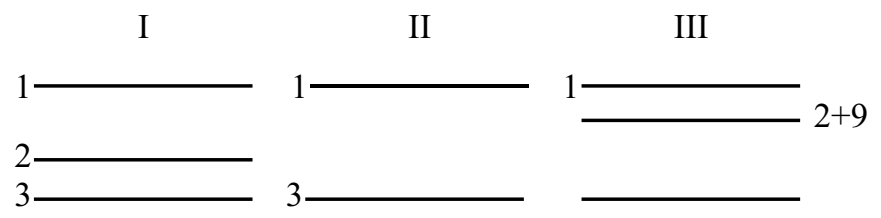

Figure 1. Schematic representation of genomic types of ADV (I, II and III) based on the migration of the first three fragments obtained by $\operatorname{BamHI}$ RFLP $(6,8)$. patterns of genomic types I and II strains are also shown in Fig. 2, lanes I and II. The year of isolation, State of origin, affected host and genomic type of the 30 ADV strains are listed in Table 1.

Herrmann et al. (8), proposed a systematization of ADV genomic types based on the genomic BamHI RFLP analysis of a large number of ADV isolates. This systematization has been adopted by different authors around the world $(1,4,5,7,9,12$, $16,17,18,20)$.

Based on the systematization of Herrmann et al. (8) and Christensen (6), the RFLP pattern of 93.33\% of the Brazilian ADV strains (28/30) could be classified as group II genomic type. Only two strains $(6.66 \%)$ were classified as group I genomic type. Group II genomic type was observed in almost all the years and States studied, while group I genomic type strains were observed only in São Paulo in 1986 and 1990 (Table 1). The three VDA strains isolated from cattle, dog and cat were classified as group II genomic types and no differences among their RFLP patterns were observed.

Table 1. Year of isolation, State of origin, host affected and genomic type of ADV strains.

\begin{tabular}{ccccc}
\hline Strain & $\begin{array}{c}\text { Year of } \\
\text { Isolation }\end{array}$ & State of Origin & Host & $\begin{array}{c}\text { Genomic } \\
\text { Type }\end{array}$ \\
\hline 1 & 82 & São Paulo & PIG & II \\
2 & 82 & Santa Catarina & PIG & II \\
3 & 83 & Santa Catarina & PIG & II \\
4 & 85 & São Paulo & CAT & II \\
5 & 86 & São Paulo & PIG & I \\
6 & 88 & Paraná & CATTLE & II \\
7 & 90 & Paraná & DOG & II \\
8 & 90 & São Paulo & PIG & I \\
9 & 90 & São Paulo & PIG & II \\
10 & 91 & São Paulo & PIG & II \\
11 & 91 & São Paulo & PIG & II \\
12 & 91 & Santa Catarina & PIG & II \\
13 & 92 & São Paulo & PIG & II \\
14 & 92 & São Paulo & PIG & II \\
15 & 92 & Santa Catarina & PIG & II \\
16 & 92 & Santa Catarina & PIG & II \\
17 & 93 & Santa Catarina & PIG & II \\
18 & 93 & Santa Catarina & PIG & II \\
19 & 93 & Santa Catarina & PIG & II \\
20 & 93 & Santa Catarina & PIG & II \\
21 & 94 & Santa Catarina & PIG & II \\
22 & 94 & Santa Catarina & PIG & II \\
23 & 94 & Santa Catarina & PIG & II \\
24 & 94 & Santa Catarina & PIG & II \\
25 & 95 & Santa Catarina & PIG & II \\
26 & 95 & Santa Catarina & PIG & II \\
27 & 95 & Santa Catarina & PIG & II \\
28 & 96 & Santa Catarina & PIG & II \\
29 & 96 & Santa Catarina & PIG & II \\
30 & 96 & Santa Catarina & PIG & II \\
\hline & & & &
\end{tabular}




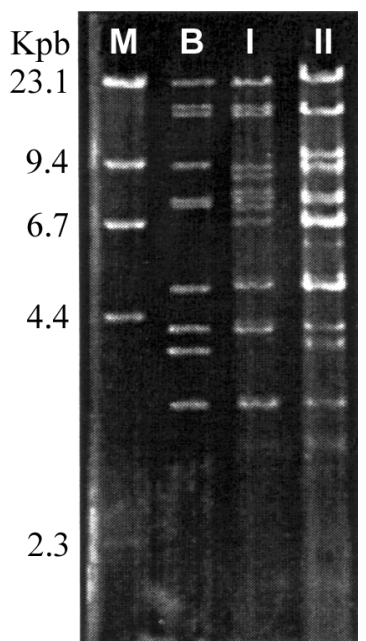

Figure 2. Restriction fragment patterns of genomic types of ADV strains. $\mathrm{M}=$ Molecular weigth marker (Lambda DNA Hind III Digest), $\mathrm{B}=$ Bartha reference strain, $\mathrm{I}=$ Genomic type $\mathrm{I} ; \mathrm{II}=$ Genomic type II., $\mathrm{Kpb}=$ kilo base pairs.

According to Hermann et al. (8), genomic type I was found in the USA and Central Europe, while genomic type II was observed in Central Europe and Japan. Genomic type III was only observed in North Europe.

In this first study of Brazilian ADV strains genomic type characterization, we could demonstrate the occurrence of the genomic types I and II in Brazil, with a large predominance of genomic type II. The genomic type III was not observed in the 30 ADV strains studied.

\section{RESUMO}

\section{Caracterização de amostras do vírus da doença de Aujeszky isoladas nas regiões sul e sudeste do Brasil por RFLP}

O DNA genômico de 30 amostras do vírus da doença de Aujeszky (VDA), isoladas nas regiões Sul e Sudeste do Brasil no período de 1982 a 1996, foram caracterizadas por análise do perfil de restrição utilizando a enzima BamHI. Vinte e sete amostras foram isoladas de suínos, uma de bovino, uma de felino e uma de canino. Através de uma sistemática previamente descrita, as 30 amostras de VDA foram classificadas como pertencentes ao tipo genômico I $(\mathrm{n}=2)$ e tipo genômico II $(\mathrm{n}=28)$. O tipo genômico III não foi observado. Neste primeiro estudo de caracterização genômica de isolados de VDA do Brasil, foi possível demonstrar a ocorrência dos tipos genômicos I e II, com marcante predomínio do tipo II.

Palavras-chave: Vírus da Doença de Aujeszky, suínos, RFLP genômico, Brasil

\section{REFERENCES}

1. Banks, M. DNA restriction fragment lenght polymorphism among British isolates of Aujeszky's disease virus: use of the polymerase chain reaction to discriminate among strains. Br. Vet. J., 149:155$163,1993$.

2. Bartha, A.; Belak S.; Benyeda, J. Trypsin and heat resistance of some strains of the herpes virus group. Acta Vet. Acad. Sci. Hung., 19:9799, 1969.

3. Baskerville, A.; Mac Ferran, J.B.; Dow, C. Aujeszky's disease in pig. Vet. Bull., 43:465-480,1973.

4. Capua, I.; Casaccia, C.; Calzeta, G.; Caporale, V. Characterization of Aujeszky's disease viruses isolated from domestic animals and from a wild boar (Sus Scrofa) in Italy between 1972 and 1995. Vet. Microbiol., 51:143-149, 1997.

5. Christensen, L.S.; Soerensen, K.J. Introduction of foreign strains of Suid herpesvirus 1 (Aujeszky's disease virus) documented by restriction fragment pattern (RFP) analysis. Arch. Virol., 100:109$113,1988$.

6. Christensen, L.S. The population biology of suid herpesvirus 1. APMIS, 103:1-48, 1995.

7. Gielkens, A.L.J.; Van Oirschot, J.T.; Berns, A.J.M. Genome differences among field isolates and vaccine strains of pseudorabies virus. J. Gen. Virol., 66: 69-82, 1985.

8. Herrmann, S.C.; Heppner, B.; Ludwig, H. Pseudorabies viruses from clinical outbreaks and latent infections grouped into four major genome types. Curr. Top. Vet. Med. Anim. Sci., 27:378-401, 1984.

9. Jestin, A.; Blanchard, P.; Garbar-Chenon, A.; Vannier, P.; Nicolas, J.C. Restriction fragment pattern analysis of genomes from French isolates of suis herpes virus 1 (Aujesky's disease virus). Arch. Virol., 112:149$167,1990$.

10. Kotait, I.; Peixoto, Z.M.; Cunha, E.S.; Queirós, L.H.; Souza, M.C.A.M.; Bersano, J.G. Focos da Doença de Aujeszky no Estado de São Paulo no período de 1982-1986. Arq. Inst. Biol., São Paulo, 53:65-70, 1986.

11. Murphy, F.A.; Fauquet, C.M.; Bishop, D.H.L.; Ghabrial, S.A.; Jarvis, A.W.; Martelli, G.P.; Mayo, M.A.; Summers, M.D. Virus Taxonomy. Classification and Nomenclature of Viruses. Sixth Report of the International Commitee on Taxonomy of Viruses. Arch. Virol., 10:120$121,1995$.

12. Nishimori, T.; Imada, T.; Sakurai, M.; Kitabayashi, T.; Kawamura, H.; Nakajima, H. Restriction endonuclease analysis of Aujesky's disease virus isolated in Japan. Jpn. J.Vet. Sci., 49:365-367, 1987.

13. Platt, K.E.; Mare, C.J.; Hinz, P.N. Differentiation of vaccine strains and field isolates of pseudorabies (Aujeszky's disease) in virus: trypsin sensitivity and mouse virulence markers. Arch. Virol., 63:107-114, 1980.

14. Romero, C.H.; Rowe, C.A.; Flores, R.S.; Brentano, L.; Marques, J.L.L. Erradicação do Vírus da Doença de Aujeszky de plantéis de reprodutores suínos através da testagem e eliminação de suínos com anticorpos. Pesq. Vet. Bras., 6:1-4, 1986.

15. Sambrook, J.; Fritsch, E.F.; Maniatis, T. Molecular Cloning: $a$ laboratory manual $2^{\text {nd }}$ edition. Cold Spring Harbor Laboratory Press. Cold Spring Harbor., 1989.

16. Shibata, I.; Asa, T.; Akashi, H.; Inaba, Y. Characterization of japanese isolates of Aujeszky's disease virus by restriction endonuclease cleavage patterns, virulence in mice and thymidine kinase activity. J. Vet. Med. Sci., 54:523-8, 1992.

17. Tisdal, D.J.; Bentley, C.B.; Horner, G. Genetic variation between New Zealand and Western Samoan isolates of Aujeszy's disease virus. Vet. Microbiol., 17:335-43, 1988.

18. Todd, D.; Mc Ferran, J.B. Restriction endonuclease analysis of Aujeszky's disease (pseudorabies) virus DNA: Comparison of Northern Ireland isolates and isolates from other countries. Arch. Virol., 86: 167-76, 1985.

19. Wittmann, G.; Rziha, H.J. Aujeszky's Disease (Pseudorabies) in pigs. In: Wittmann (ed). Herpesvirus diseases of cattle, horses and pigs. Boston, Kluwer, 1989, p.230-235.

20. Yamada, S.; Nishimori, T.; Shimizu, M. Characterization of pseudorabies viruses recently isolated in Japan by restriction endonuclease assay. $J$. Vet. Med. Sci., 54:541-49, 1992. 